I RECORDS ADMINISTRATION

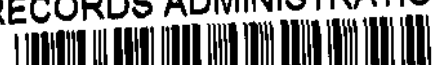

R0139097

DP-1507

q

TIS FILE

RFCORD COPY

\title{
VISCOSITY OF GLASSES CONTAINING SIMULATED SAVANNAH RIVER PLANT WASTE
}

\author{
M. J. PLODINEC
}

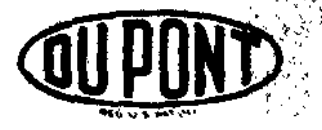

\section{SAVANNAH RIVER LABORATORY} AIKEN, SOUTH CAROLINA 29801 
NOTICE

This report was prepared as an account of work sponsored by the United States Government. Neither the United States nor the United States Department of Energy, nor any of their contracturs, subcontractors, or their employees, makes any warranty. express or implied or assumes any legal liability or responsibility for the accuracy, completeness or usefulness of any information, apparatus, product or process disclosed, or represents that its use would not infringe privately owned rights.

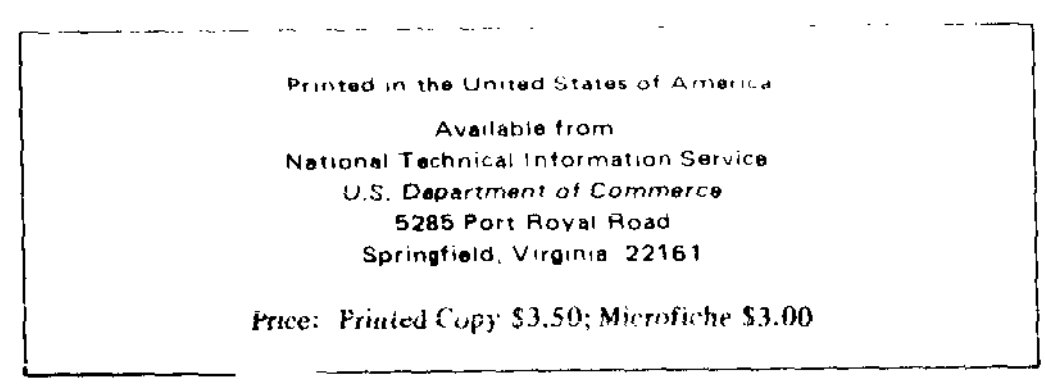


DP-1507

Distribution Category: UC-70

\section{VISCOSITY OF GLASSES CONTAINING SIMULATED SAVANNAH RIVER PLANT WASTE}

by

M. J. Plodinec

Approved by

M. L. Hyder, Research Manager

Separations Chemistry Division

Pub1ication Date: August 1978

E. I. DU PONT DE NEMOURS AND COMPANY SAVANNAH RIVER LABORATORY AIKEN, SOUTH CAROLINA 29801

PREPARED FOR THE U.S. DEPARTMENT OF ENERGY UNDER CONTRACT ATI(07-2)-1 


\section{ABSTRACT}

The viscosity of glass melts containing four simulated sludge types and two frit candidates (Frits 18 \& 21) were measured over the temperature range $750-1200^{\circ} \mathrm{C}$. The viscosity of melts made with either frit was reduced by the addition of high iron sludge, unchanged by average sludge, and increased by composite and high aluminum sludge. High aluminum sludge greatly increased the viscosity. Frit 21 (containing 4 wt $\% \mathrm{Li}_{2} \mathrm{O}$ substituted for $4 \mathrm{wt} \%$ $\mathrm{Na}_{2} \mathrm{O}$ in Frit 18), was clearly better than Frit 18 in terms of its low viscosity. However, further reductions in viscosity are desirable, especially for glasses containing high aluminum sludge.

Changing any frit component by 1 wt $\%$ did not significantly affect the viscosity of the glasses. Therefore, a variability of 1 wt $\%$ in any frit component can be tolerated. 


\section{CONTENTS}

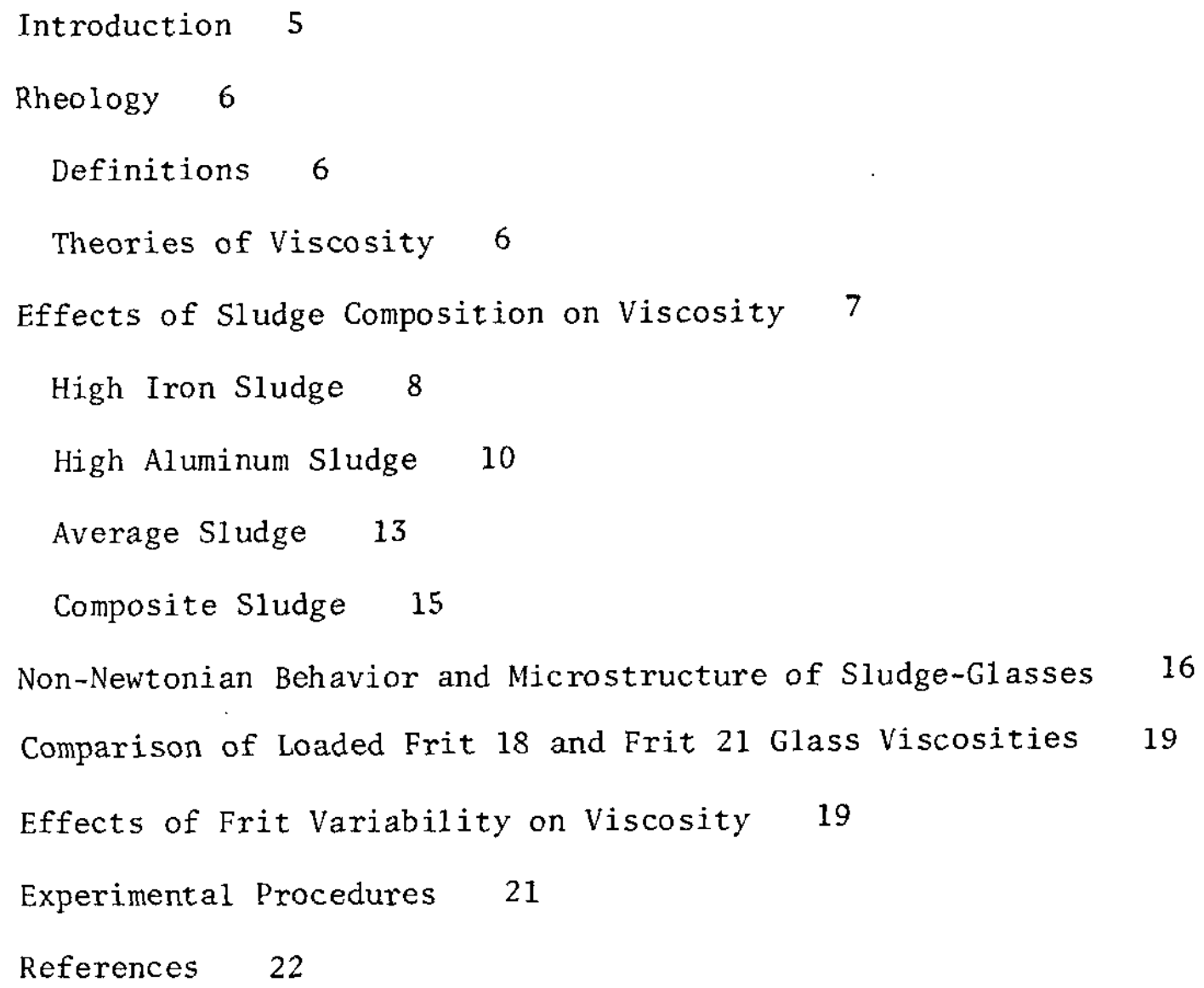




\section{LIST OF TABLES}

1 Composition of Glass Frits 8

2 Composition of Simulated Calcined Sludges 9

3 Constants for Fulcher's Equation 10

4 Rheology of Non-Newtonian Me1ts 16

5 Effects of Frit Variations on Viscosity 20

\section{LIST OF FIGURES}

1 Viscosity of Glasses Containing Simulated High Iron Sludge $\mathfrak{g}$

2a Viscosity of Glasses Containing Simulated High Aluminum Sludge in Frit $21 \quad 11$

2b Viscosity of Glasses Containing Simulated High Aluminum Sludge in Frit $18 \quad 12$

3 Viscosity at $1150^{\circ} \mathrm{C}$ of High Aluminum Sludge-Frit 21 Melts 13

4 Viscosity of Glasses Containing Simulated Average Sludge

5 Viscosity of Glasses Containing Similated Composite Sludge 15

6 Glasses with Little or No Spinel Formation 17

7 Glasses with Extensive Spine1 Formation 18

8 Schematic of Viscosity Apparatus 21 


\section{VISCOSITY OF GLASSES CONTAINING SIMULATED SRP WASTE}

\section{INTRODUCTION}

The Savannah River Laboratory has evaluated severa1 materials for solidification and storage of Savannah River Plant (SRP) highlevel liquid radioactive waste. ${ }^{1-10}$ Borosilicate glass was determined to be the preferred material, based on leachability, ease of processing, and safety during transportation.

The viscosity and its dependence on temperature is the single most important variable in glass processing. 1 Viscosity determines the rate of melting of the raw feed, the rate of gas bubble release (fining), the rate of homogenization, and thus, the quality of the final glass product. For all of these parameters, the viscosity should be as low as possible.

Two processes for solidifying SRP waste into glass are currently under study. In one method, in-can melting, glass frit and calcined waste are vitrified in a canister which eventually goes to final storage. In the other method, joule-heated melting, the glass frit and calcine are fed continuously to a ceramic melter, vitrified, and then poured into the storage canister.

Of the two glass-me1ting processes, continuous joule-heated melting requires a lower viscosity. In the melter, the melt must flow well enough to give good mixing and to ensure adequate heat transfer. However, if the viscosity is too low, excessive convection currents can occur, increasing corrosion/erosion of the melter materials (refractories and electrodes) and making control of the melter more difficult. This means that the glass viscosity should be 10-50 poise (p) in the melter. The glass must pour continuously into a container, but does not do so above $500 \mathrm{p}$. This can reduce product quality by causing voids in the final waste form.

For good melting by the in-can method, a viscosity $\leqslant 200$ poise is necessary. This viscosity ensures adequate homogenization of the waste and frit, and a reasonable melting rate. An additional constraint is imposed by the corrosion of canister materials. If stainless steel is used, the viscosity must be $\leqslant 200$ poise below $1050^{\circ} \mathrm{C}$. If Inconel alloys are used, the viscosity must be $\leqslant 200$ poise, but the temperature limit would be $1150^{\circ} \mathrm{C}$.

This report examines the effects of various sludges on the viscosity of glasses prepared from two frit candidates (Frits 18 and 21). Sludge loadings and compositions spanned the expected range for SRP waste glass. 
RHEOLOGY

Definitions

Most fluids obey the following equation for mass flow:

$$
\sigma=\mathrm{mS}^{\mathrm{n}}
$$

where $\sigma=$ shear stress, $S=$ rate of shear, and $m$ and $n$ are functions of composition and temperature. When $n=1$, the fluid is said to be Newtonian, and $m=n,(n=v i s c o s i t y)$. When $n<1$, the material is pseudo-plastic. If $n$ (or $m$ ) depends on the amount of shearing, the material is thixotropic. ${ }^{12}$

The fluidity, $\phi$, is the reciprocal $(1 / \eta)$ of the viscosity $(n)$. Thus, a liquid is more fluid when it is less viscous.

\section{Theories of Viscosity}

There are three basic groups of viscosity theories. The largest group is composed of purely empirical relationships, such as power series in $1 / T$ or $T$, exponential functions of $1 / T$ or $T$, and sums and/or quotients of these. While these may be rationalized on various theoretical grounds, they are best judged by accuracy and ease of application. ${ }^{3}$

The second group of theories is based on the Arrhenian model of material flow in which the fluidity is treated as a rate constant:

$$
\begin{aligned}
\phi & =\exp (-\Delta G / R T) \\
& =\exp \left(-\Delta G_{v i s} / R T\right)
\end{aligned}
$$

where $\Delta G_{v i s}$ is the free energy of activation for viscous flow.

Thus,

$$
\begin{gathered}
\eta=\exp \left(\Delta \mathrm{G}_{\text {vis }} / \mathrm{RT}\right) \\
\text { In } \eta=\frac{\Delta \mathrm{G}_{\text {Vis }}}{\mathrm{RT}}=\frac{\Delta \mathrm{S}_{\text {Vis }}}{\mathrm{R}}+\frac{\Delta \mathrm{E}_{\text {Vis }}}{\mathrm{RT}}
\end{gathered}
$$

The simplest version of this theory assumes that $\Delta S_{v i s}$ (the entropy of activation for viscous flow) and $\Delta E_{v i s}$ (the energy of activation for viscous flow) are independent of temperature. Thus, a plot of $\log n$ vs. $1 / T$ should be linear. This is not true for glass, because the temperature dependence of the glass viscosity is much stronger. At this point, such theories must rely on empirically determined constants to express the temperature dependence of $\Delta E_{v i s}$. 
The third group of theories are those based on free volume. ${ }^{14}$ These generally assume that the viscosity, $n$, is a function of the free volume (V). The free volume at a temperature $(T)$ is assumed to be the difference between the liquid volume at temperature $T$, $\mathrm{V}_{\mathrm{T}}$, and the liquid volume at some reference $\mathrm{T}_{\mathrm{o}}(<\mathrm{T}), \mathrm{V}_{\mathrm{o}}$.

$$
\eta=n\left(V_{T}-V_{0}, T\right)
$$

For glasses, $T_{0}$ is generally the glass transition temperature. The usual procedure is to assume.

$$
V_{T}=V_{0}\left[1+\alpha\left(T-T_{0}\right)\right]
$$

where $\alpha$ is the coefficient of expansion. Thus,

$$
\eta=n\left(\alpha, v_{0}, T-T_{0}\right)
$$

Such theories lead to expressions of the form

$$
\log n=A+\frac{B}{T-T_{0}}
$$

Equation 2 is the Fulcher equation, which has proven most useful in representing glass viscosities. ${ }^{5,16}$, Though Equation 2 was originally proposed on a theoretical basis, it is currently used empirically with $A, B$, and $T$ derived from the experimental data. No physical meaning should be attached to their values. In this work viscosities of Newtonian melts will be reported in terms of Equation 2. Non-Newtonian melts, $\mathrm{n}<1$, will be characterized in terms of Equation 1 .

\section{EFFECTS OF SLUDGE COMPOSITION ON VISCOSITY}

G1ass melts were prepared from two borosilicate glass frits, Frits 18 and 21 . Frit 21 differs from Frit 18 by the substitution of 4 wt $\% \mathrm{Li}_{2} \mathrm{O}$ for 4 wt $\% \mathrm{Na}_{2} \mathrm{O}$ (Table 1 ).

Four simulated sludge types were used: high iron, high aluminum, average, and composite. High iron and high aluminum sludges reflect the extremes of compositions found in samples of actual SRP sludges. ${ }^{3,4,10}$ Average sludge is the arithmetic average of compositions sampled prior to this work. Composite sludge is a weighted average, reflecting the relative amounts of sludge in sampled tanks. 
TABLE 1

Composition of Glass Frits

\begin{tabular}{|c|c|c|c|c|}
\hline \multirow[b]{2}{*}{ Component } & \multicolumn{2}{|c|}{ Frit 18} & \multicolumn{2}{|c|}{ Frit 21} \\
\hline & Wt \% & Mole \% & Wt \% & Mole \% \\
\hline $\mathrm{SiO}_{2}$ & 52.5 & 54.8 & 52.5 & 52.5 \\
\hline $\mathrm{Na}_{2} \mathrm{O}$ & 22.5 & 22.8 & 18.5 & 17.9 \\
\hline $\mathrm{B}_{2} \mathrm{O}_{3}$ & 10.0 & 9.0 & 10.0 & 8.65 \\
\hline $\mathrm{TiO}_{2}$ & 10.0 & 7.8 & 10.0 & 7.5 \\
\hline $\mathrm{CaO}$ & 5.0 & 5.6 & 5.0 & 5.35 \\
\hline $\mathrm{Li}_{2} \mathrm{O}$ & -- & -- & 4.0 & 8.1 \\
\hline
\end{tabular}

The viscosities of g1ass melts containing Frits 18 and 21 , and the four types of simulated sludge were measured over the temperature range $750-1200^{\circ} \mathrm{C}$. At the same temperature and amount of sludge, the viscosity of the glass melt increased according to sludge composition in the order high iron, average, composite, and high aluminum sludge. Frit 21 glasses were 1 ess viscous than Frit 18 glasses, at the same temperature and amount of sludge. The viscosity depended on the amount of aluminum $\left(\right.$ as $\mathrm{Al}_{2} \mathrm{O}_{3}$ ) and iron (as $\mathrm{Fe}_{2} \mathrm{O}_{3}$ ) contained in the sludge. Other sludge components had little effect. Sludges which contained large amounts of $\mathrm{Fe}_{2} \mathrm{O}_{3}$ ( $\geq 35$ wt $\left.\%\right)$ caused melts containing either frit to become non-Newtonian. Results for non-Newtonian melts are discussed in detail in a later section.

\section{High Iron Sludge}

High iron sludge in amounts $\leqslant 30 \mathrm{wt} \%$ decreased the viscosity of the glasses made with either frit. Larger proportions of this sludge increased the viscosity of the glass melt, and caused non-Newtonian behavior. However, no problems are foreseen in processing normal amounts of this sludge.

Glasses were prepared containing $25,30,35$, and 45 wt $\%$ high iron sludge in Frits 18 and 21 . High iron sludge composition (Table 2) simulates the calcined form of a sample composed of sludge from SRP tanks 4 and 6 . Actual waste forms will contain 25-30 wt $\%$ calcined sludge.

Viscosities of glasses containing 25 and $30 \mathrm{wt} \%$ high iron sludge are plotted in Figure 1, with data for pure Frits 18 and 21 plotted for reference. High iron sludge decreases the viscosity of the glass above $\sim 1050^{\circ} \mathrm{C}$. At lower temperatures, the viscosity 
of high iron sludge melts increased more quickly relative to the pure frits. The Fulcher parameters $A, B$, and $T_{0}$ for all Newtonian melts containing pure Frits 18 and 21 are listed in Tab1e 3 . Melts containing 35 and 45 wt $\%$ high iron sludge were non-Newtonian.

TABLE 2

Composition of Simulated Calcined Sludges

\begin{tabular}{|c|c|c|c|c|c|c|c|}
\hline \multirow{3}{*}{ szudge } & \multicolumn{7}{|c|}{ Component, wt \% } \\
\hline & $\mathrm{Fe}_{2} \mathrm{O}_{3}$ & $\mathrm{Al}_{2} \mathrm{O}_{3}$ & $\mathrm{MnO}_{2}$ & $U_{3} \mathrm{O}_{8}$ & $\mathrm{Nd}_{2} \mathrm{O}_{3}$ & $\mathrm{CaO}$ & NiO \\
\hline & \multicolumn{7}{|c|}{ Sludges Containing Uranium } \\
\hline Average & 43.5 & 25.8 & 11.7 & 11.0 & - & 3.0 & 5.0 \\
\hline High Iron & 61.4 & 5.6 & 4.1 & 14.2 & - & 4.2 & 10.5 \\
\hline High Aluminum & 6.0 & 86.3 & 4.9 & 1.5 & - & 0.4 & 0.9 \\
\hline Composite & 31.6 & 46.4 & 10.3 & 6.1 & - & 3.3 & 2.3 \\
\hline
\end{tabular}

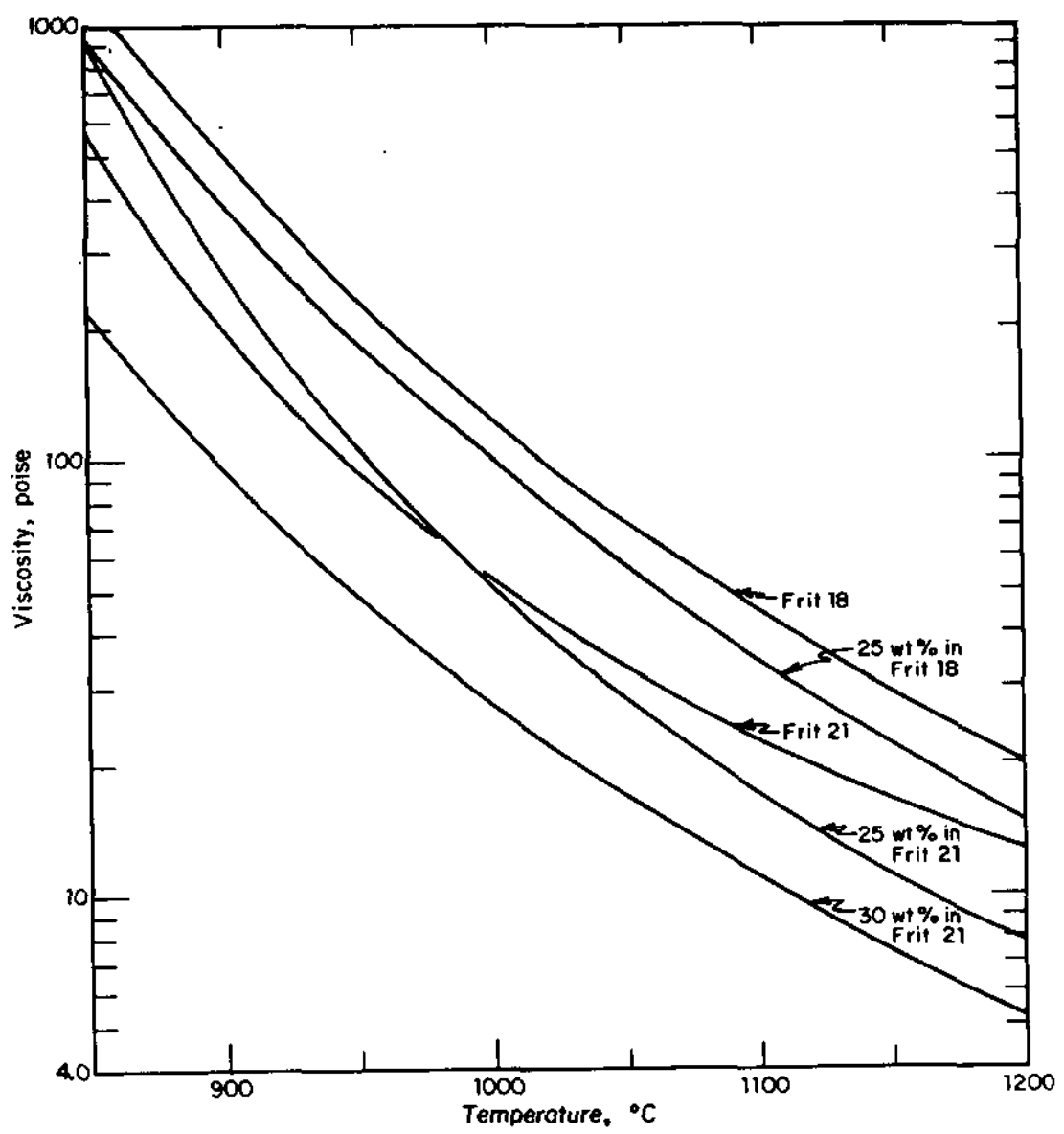

FIGURE 1. Viscosity of Glasses Containing Simulated High Iron STudge 
TABLE 3

Constants for Fulcher's Equation

$\log n=A+B /\left(T-T_{0}\right) \quad\left(n\right.$ in poise, $T$ in $\left.{ }^{\circ} \mathrm{C}\right)$

Sludge $\quad$ Amount, wt \% $\quad \underline{A} \quad \underline{B} \quad \underline{T_{0}}$

Melts Made with Frit 21

$\begin{array}{lrrrr}\text { None } & -- & -0.271 & 887 & 556 \\ \text { High Iron } & 25 & -1.157 & 1420 & 505 \\ & 30 & -1.701 & 2136 & 320 \\ \text { High Aluminum } & 10 & -0.563 & 1721 & 344 \\ & 15 & -1.216 & 3043 & 158 \\ & 20 & -0.575 & 2340 & 240 \\ & 25 & -1.261 & 2695 & 331 \\ \text { Average } & 35 & 1.753 & 191 & 921 \\ & 25 & -1.445 & 2083 & 402 \\ \text { Composite } & 30 & -3.977 & 5762 & 69 \\ & 20 & -1.156 & 2538 & 228 \\ & 25 & -0.722 & 1702 & 411 \\ & 30 & -0.435 & 1461 & 480\end{array}$

Melts Made with Frit 18

$\begin{array}{lllll}\text { None } & -- & -1.307 & 2239 & 342 \\ \text { High Iron } & 25 & -2.176 & 3356 & 196 \\ \text { High Al uminum } & 25 & -2.647 & 6304 & -94 \\ \text { Average } & 25 & -1.398 & 2716 & 262 \\ & 35 & -1.726 & 2626 & 388 \\ \text { Composite } & 25 & -2.509 & 4475 & 159\end{array}$

\section{High ATuminum STudge}

High aluminum sludge greatly increased the viscosity of the glass. As little as $15 \mathrm{wt} \%$ of this sludge in Frit 21 caused the viscosity to exceed the 1 imit of 50 poise for all temperatures below $1200^{\circ} \mathrm{C}$. Thus, vitrifying large amounts of this sludge requires special care. Frit 18 is not suitable for processing this sludge below $1150^{\circ} \mathrm{C}$.

Glasses were prepared containing $10,15,20,25,35$, and 45 wt $\%$ high aluminum sludge in Frit 21 and 25,35 and $45 \mathrm{wt} \%$ high aluminum sludge in Frit 18. This sludge composition (Table 2) simulates the calcined form of a sludge sample taken from SRP Tank 15. The samples containing $45 \mathrm{wt} \%$ high aluminum sludge in Frit 21 and 35 wt $\%$ in Frit 18 were non-Newtonian, due to presence of unmelted batch. Therefore, data for these samples are omitted. 
Viscosities of glasses containing up to 35 wt $\%$ high aluminum sludge are plotted as functions of temperature in Figures $2 \mathrm{a}$ and $\mathrm{b}$ and show a strong composition dependence. This dependence on composition is also shown in Figure 3, where $\log \eta$ at $1150^{\circ} \mathrm{C}$ is plotted against the amount of high aluminum sludge for glasses containing Frit 21 . This plot is linear and the least squares fit to the data gives the equation

$$
\eta\left(1150^{\circ} \mathrm{C}\right)=16.8 \exp \left(0.085 \mathrm{P}_{\mathrm{A} 1}\right)
$$

where $\mathrm{P}_{\mathrm{Al}}=\mathrm{wt} \%$ high aluminum sludge in the glass. The Fulcher parameters for all the Newtonian melts are in Table 3.

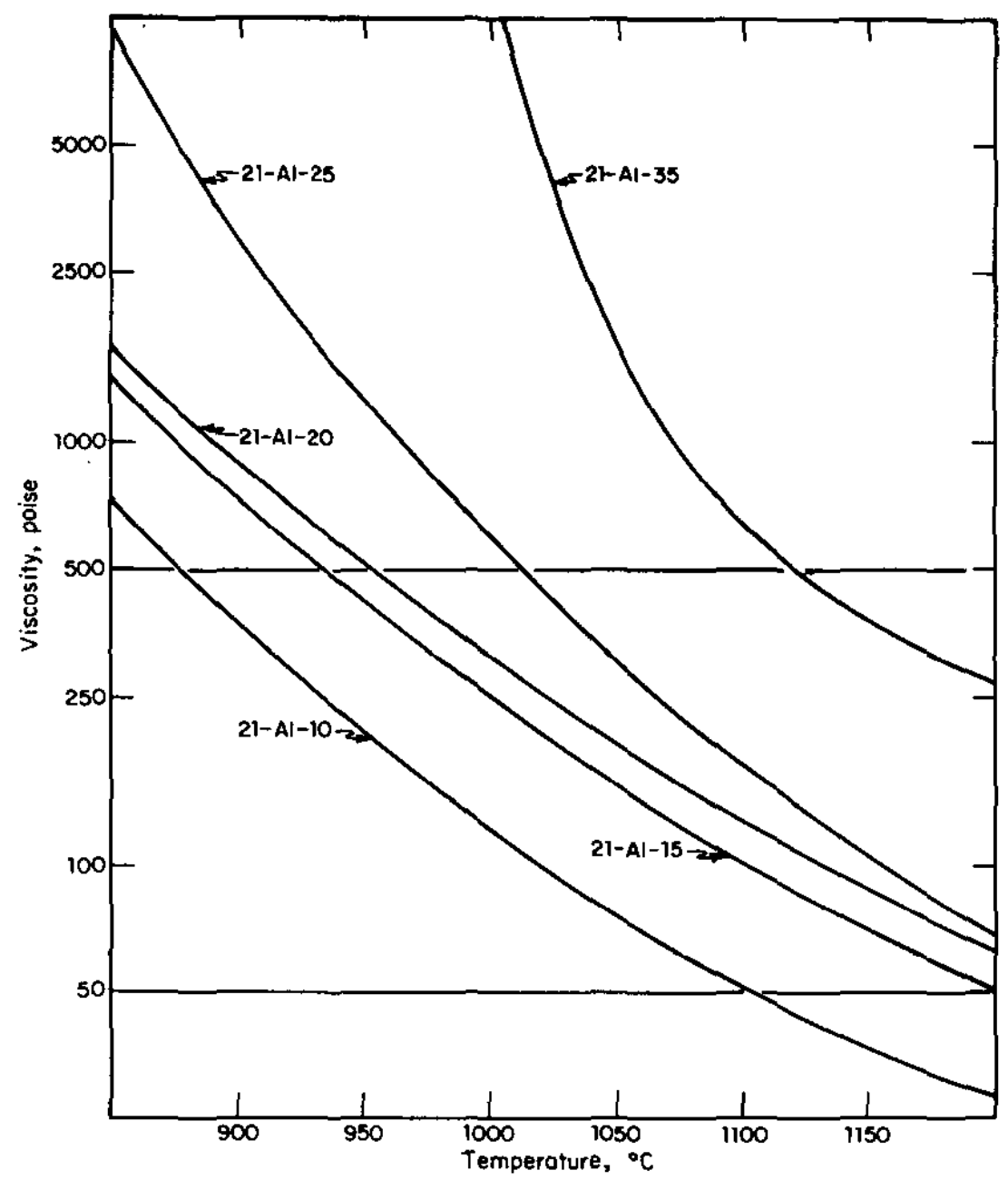

FIGURE 2a. Viscosity of Glasses Containing Simulated High Aluminum Sludge in Frit 21 


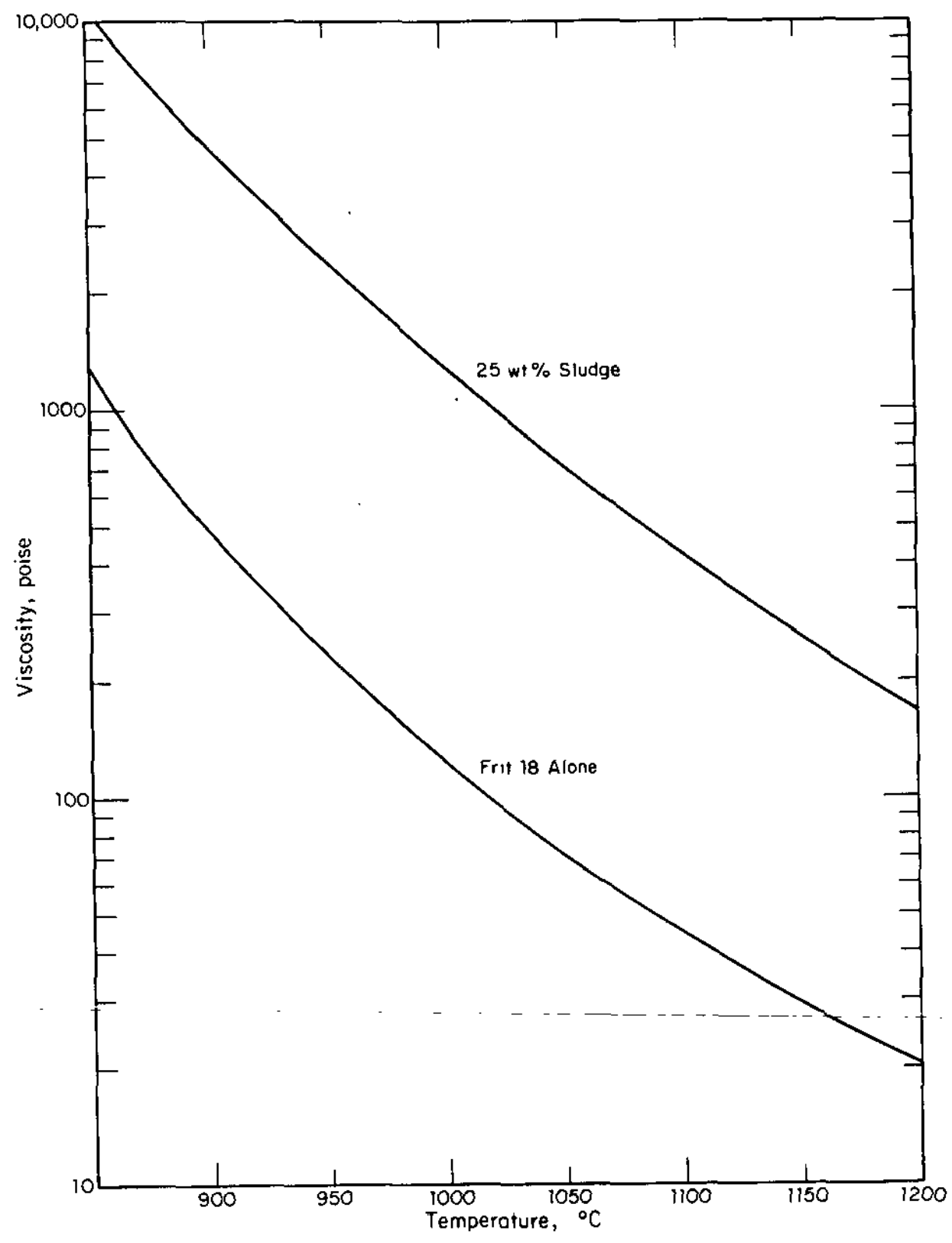

FIGURE 2b. Viscosity of Glass Containing Simulated High Aluminum Sludge in Frit 18 


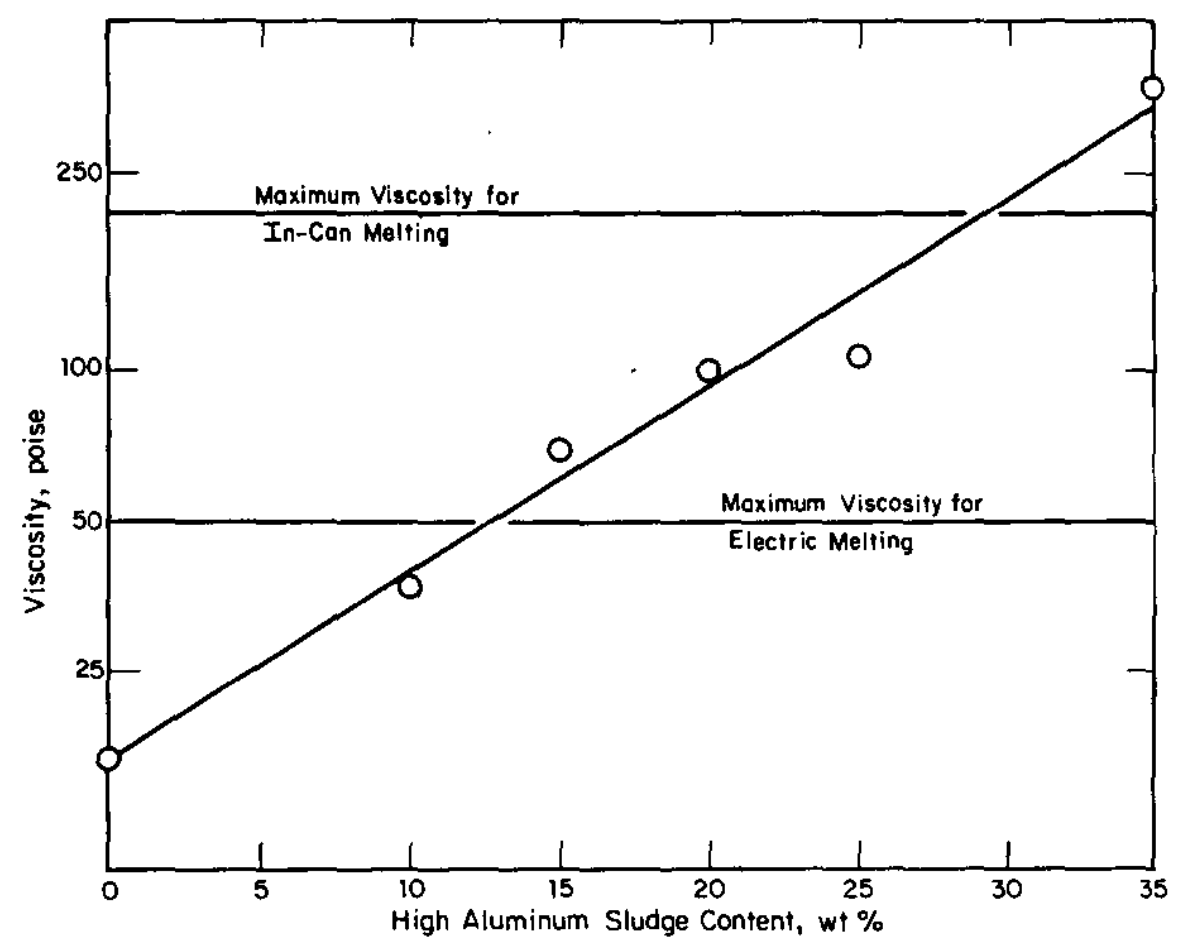

FIGURE 3. Viscosity at $1150^{\circ} \mathrm{C}$ of High Aluminum Sludge-Frit 21 Melts (Line is calculated least squares $f i t$ )

To reach $50 \mathrm{p}$ at $1150^{\circ} \mathrm{C}, \sim 12.5$ wt $\%$ high aluminum sludge could be vitrified using Frit 21 . However, for in-can melting, $\sim 30$ wt \% high aluminum sludge could be incorporated in Frit 21 before the limit of $200 \mathrm{p}$ was reached (at $1150^{\circ} \mathrm{C}$ ). Only half as much aluminum could be incorporated in Frit 18 as was in Frit 21 . Since extremely high temperatures or large reductions in the sludge/frit ratio would be required for normal processing of high aluminum sludge in Frit 18, this frit is not suitable for processing high aluminum sludge.

\section{Average Sludge}

The viscosities of me1ts containing up to $30 \mathrm{wt} \%$ average sludge were approximately the same as the viscosities of pure frit. At lower temperatures $\left(<1000^{\circ} \mathrm{C}\right)$ the viscosity of these melts increased more quickly than the viscosity of the pure frit. Glasses containing larger amounts of this sludge were viscous, non-Newtonian fluids. However, no problems are foreseen in processing normal amounts of these sludge.

G1asses were prepared containing $25,30,35$, and $45 \mathrm{wt} \%$ average sludge in Frit 21 , and 25,35 and $45 \mathrm{wt} \%$ average sludge in Frit 18. Average sludge composition is the arithmetic average calculated from analyses of 20 sludge samples from 9 tanks, simulating calcined sludge form (Table 2). 
The viscosities of glasses containing up to $35 \mathrm{wt} \%$ average sludge are plotted as functions of temperature in Figure 4. Data for Frits 18 and 21 alone are plotted for reference. The addition of sludge did not greatly increase the viscosity at temperatures $>1050^{\circ} \mathrm{C}$. At lower temperatures, the viscosity of the sludge glasses increases more rapidly than those of the pure frits. Melts containing 35 and $45 \mathrm{wt} \%$ average sludge in Frit 21 were non-Newtonian.

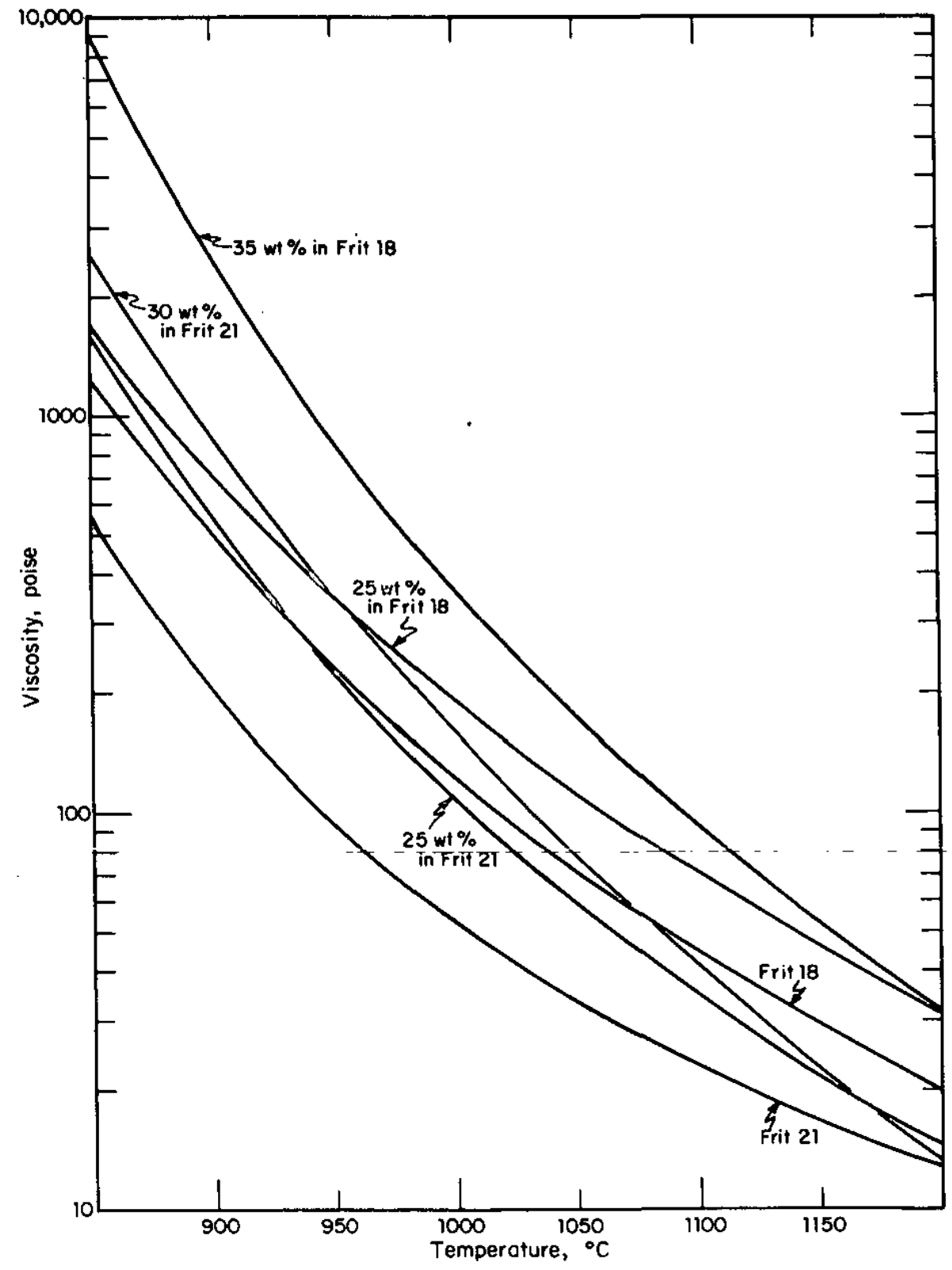

FIGURE 4. Viscosity of Glasses Containing Simulated Average Sludge 


\section{Composite Sludge}

Melts containing composite sludge were more viscous than pure Frit 21 . A glass melt containing 35 wt \% composite sludge in Frit 21 was non-Newtonian. However, no problems are foreseen in processing normal amounts of this sludge ( 25 wt \%).

Glasses were prepared containing $20,25,30$, and 35 wt $\%$ composite sludge in Frit 21 , and $25 \mathrm{wt} \%$ sludge in Frit 18 . This sludge composition is a weighted average derived from the analyses of each tank, weighted by the fraction of SRP sludge contained in that tank, and then converted to the oxides so as to simulate calcine (Table 2).

The viscosities of glasses containing 20,25 , and $30 \mathrm{wt} \%$ composite sludge are plotted as functions of temperature in Figure 5. Data for Frits 18 and 21 are plotted for reference. As the amount of added sludge increases, the viscosity increases at any given temperature relative to pure frit. The melt containing $35 \mathrm{wt} \%$ composite sludge was non-Newtonian.

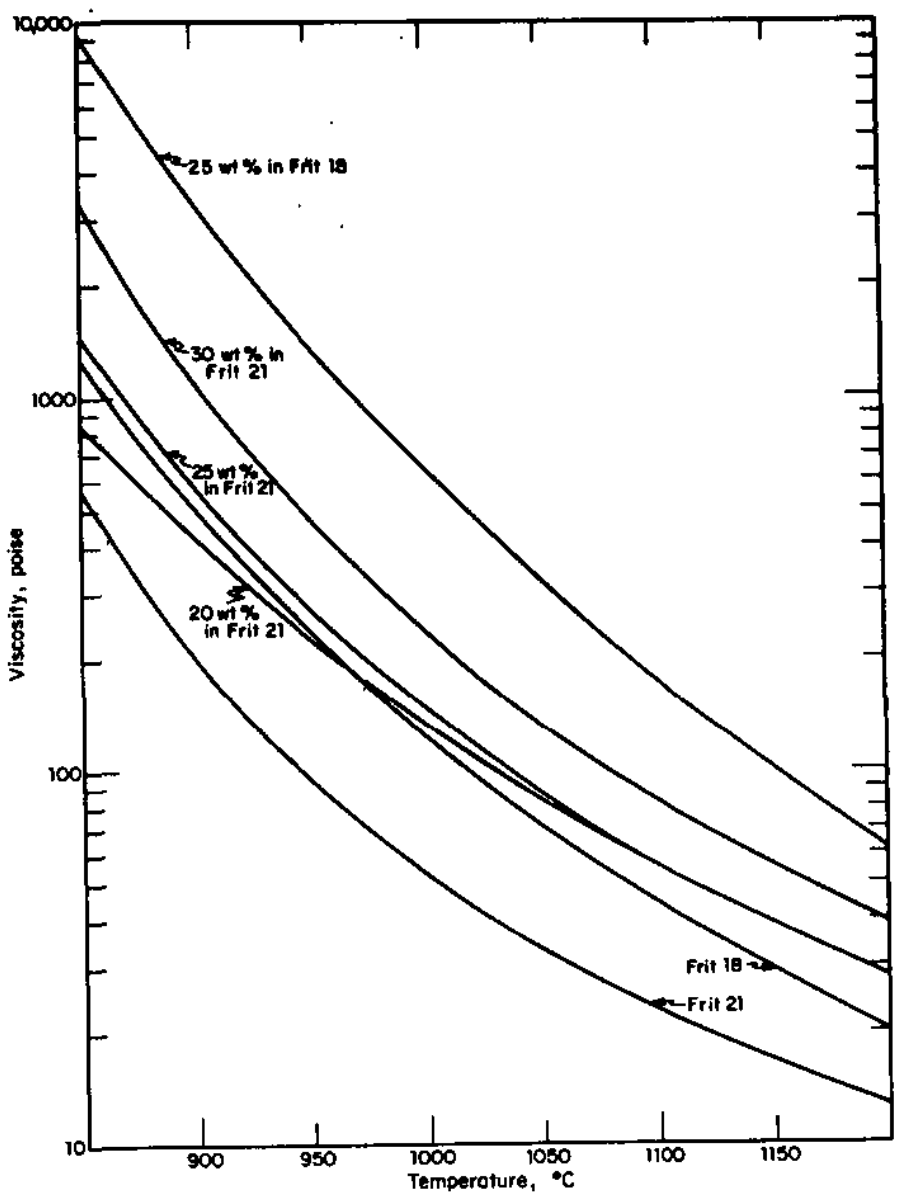

FIGURE 5. Viscosity of Glasses Containing Simulated Composite Sludge 


\section{NON-NEWTONIAN BEHAVIOR AND MICROSTRUCTURE OF SLUDGE-GLASSES}

Me1ts of Frit 18 and Frit 21 containing $\geqslant 35$ wt $\%$ of sludges with large amounts of $\mathrm{Fe}_{2} \mathrm{O}_{3}$ (high iron, average, or composite sludges) have large numbers of ferrite-spinel crystals suspended in the melt. These melts are also non-Newtonian. Their rheological behavior is similar to that of colloidal suspensions.

Glasses containing 35 wt \% high iron, average, or composite sludge, or $45 \mathrm{wt} \%$ of any of the sludges were non-Newtonian and did not have a true viscosity. However, experimental results could be represented reasonably well by fitting the data to Equation 1. Values of $m$ and $n$ were determined at several temperatures for these melts by the method of least squares. The values listed in Table 4 are accurate to within $20 \%$.

TABLE 4

Rheology of Non-Newtonian Melts

$\sigma=m S^{n} \quad\left(\sigma\right.$ in dyne $\cdot c m, S$ in $\left.\sec ^{-1}\right)$

Sludge $\quad \underline{\text { Frit }} \quad \underline{\text { Amount }(w t \%)} \quad \underline{T\left(^{\circ} \mathrm{C}\right)} \quad \underline{m} \quad \underline{n}$

High Iron

21

35

1200

450

0.59

$1150 \quad 834 \quad 0.53$

$\begin{array}{lll}1100 & 1330 & 0.46\end{array}$

$\begin{array}{lll}1050 & 1700 & 0.46\end{array}$

\begin{tabular}{|c|c|c|c|c|c|c|}
\hline & & & & 1000 & 2450 & 0.49 \\
\hline & & 45 & & $\begin{array}{l}1200 \\
1100 \\
1000\end{array}$ & $\begin{array}{l}1830 \\
4090 \\
6360\end{array}$ & $\begin{array}{l}0.54 \\
0.59 \\
0.48\end{array}$ \\
\hline \multirow[t]{2}{*}{ Average } & 21 & 35 & $-\quad-$ & $\begin{array}{r}1200 \\
1150 \\
1100 \\
1050 \\
-1000\end{array}$ & $\begin{array}{r}877 \\
1550 \\
2320 \\
3090 \\
-\quad-4460\end{array}$ & $\begin{array}{r}0.69 \\
0.60 \\
0.52 \\
0.52 \\
-\quad 0.52\end{array}$ \\
\hline & & 45 & & $\begin{array}{l}1200 \\
1100\end{array}$ & $\begin{array}{l}3140 \\
7720\end{array}$ & $\begin{array}{l}0.56 \\
0.46\end{array}$ \\
\hline Composite & 21 & 35 & & $\begin{array}{l}1200 \\
1150 \\
1100 \\
1050\end{array}$ & $\begin{array}{l}1220 \\
1750 \\
3070 \\
6670\end{array}$ & $\begin{array}{l}0.72 \\
0.69 \\
0.63 \\
0.80\end{array}$ \\
\hline \multirow[t]{2}{*}{ High Iron } & 18 & 35 & & $\begin{array}{l}1200 \\
1150 \\
1100 \\
1050 \\
1000\end{array}$ & $\begin{array}{r}742 \\
1330 \\
1850 \\
2360 \\
4260\end{array}$ & $\begin{array}{l}0.62 \\
0.48 \\
0.48 \\
0.48 \\
0.53\end{array}$ \\
\hline & & 45 & & $\begin{array}{l}1200 \\
1100 \\
1000\end{array}$ & $\begin{array}{l}1030 \\
2210 \\
3640\end{array}$ & $\begin{array}{l}0.43 \\
0.56 \\
0.46\end{array}$ \\
\hline Average & 18 & 45 & & $\begin{array}{l}1200 \\
1100 \\
1000\end{array}$ & $\begin{array}{r}3980 \\
6550 \\
23100\end{array}$ & $\begin{array}{l}0.49 \\
0.56 \\
0.61\end{array}$ \\
\hline
\end{tabular}


The effects of the different sludges on the viscosity of the melt were qualitatively similar to those observed for the Newtonian melts. At a given temperature, amount of sludge, and rate of shear, the viscosity of the sludge glasses increased (m increased) in the order high iron, average, and then composite sludge glass. These melts became more Newtonian as the temperature increased (n approached 1). At $1000^{\circ} \mathrm{C}$, $\mathrm{n}$ was near 0.5 for all except $35 \mathrm{wt} \%$ average sludge in Frit 18. At temperatures below $1000^{\circ} \mathrm{C}$, all the non-Newtonian melts became thixotropic ${ }^{12}$; thus, results are not reported below this temperature.

Non-Newtonian flow is typical of the rheological behavior of suspensions. ${ }^{17}$ As Figure 6 shows, glasses containing 25 wt \% high iron sludge have only a few isolated crystals. Glasses containing 35 wt $\%$ high aluminum sludge have no crystals. However, glasses containing 35 wt \% high iron, average, or composite sludge have many more crystals, which tend to agglomerate (Figure 7).

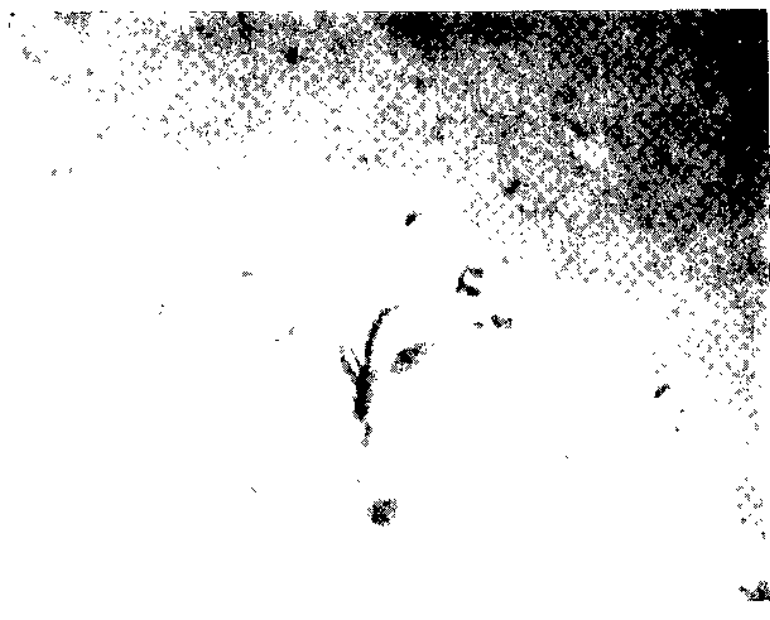

a. 25 wt $\%$ High Fe Sludge + Frit 21

b. 35 wt \% High Al Sludge + Frit 21

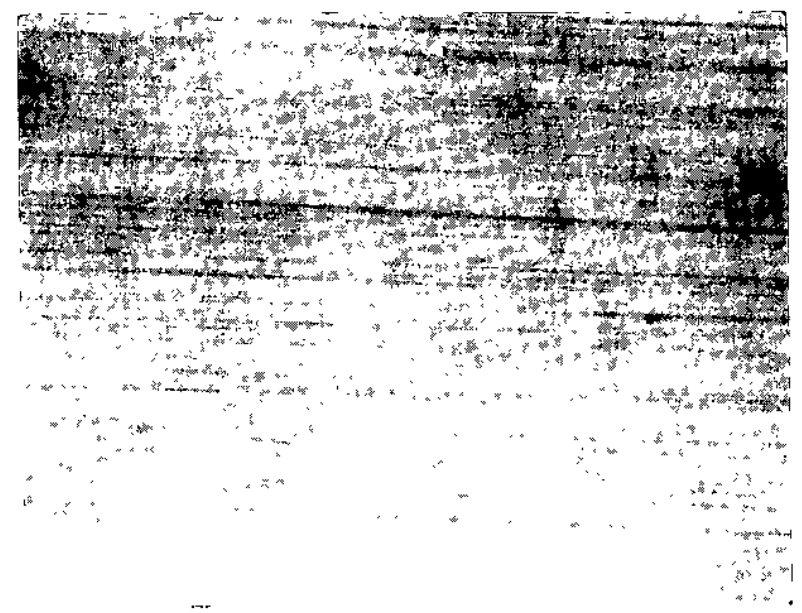

FIGURE 6. Glasses with Little or No Spinel Formation. Me1ts were Newtonian (Photos 300X) 


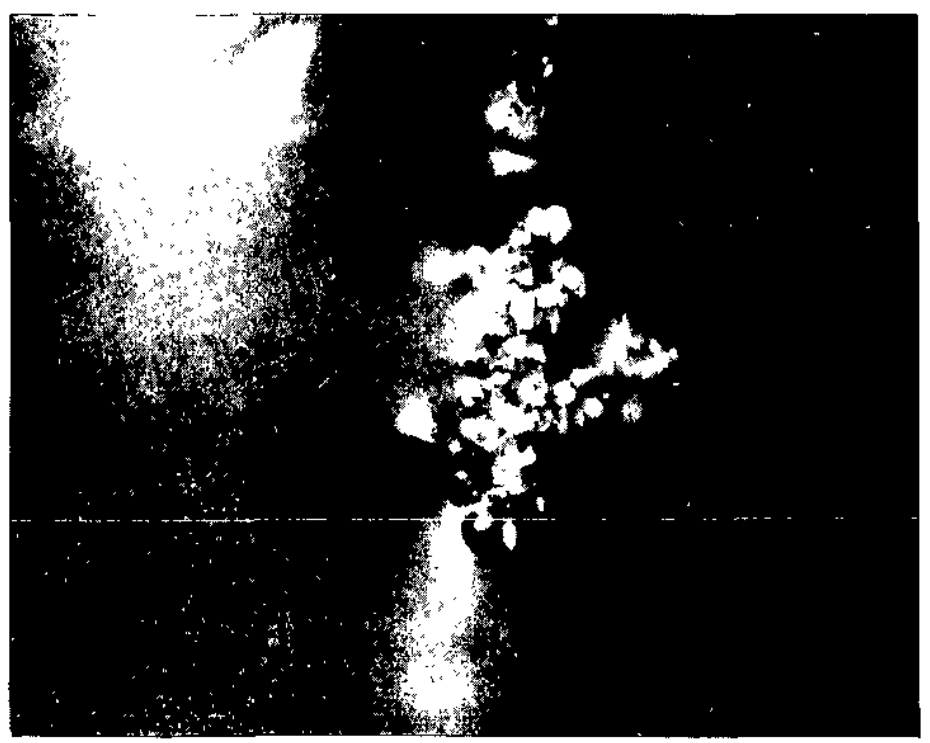

a. 35 wt \% High Fe Sludge + Frit 21

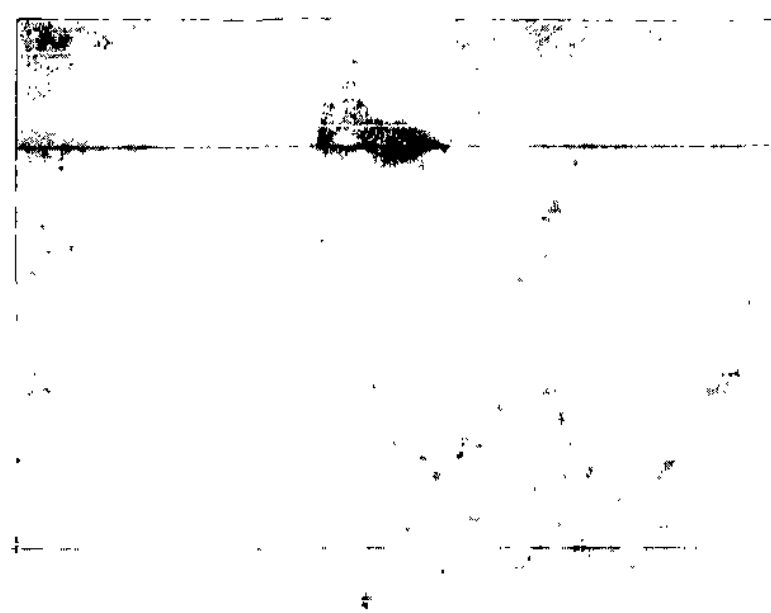

b. 35 wt $\%$ Average Sludge + Frit 27

FIGURE 7. Glasses with Extensive Spinel Formation. Melts were non-Newtonian. (Photos 300X) 


\section{COMPARISON OF LOADED FRIT 18 AND 21 GLASS VISCOSITIES}

Frit 18 melts are much more viscous than those containing Frit 21. At a given temperature, sludge composition and loading, a glass containing Frit 18 is two to three times more viscous than glass containing Frit 21. For normal amounts of composite or high aluminum sludge, Frit 18 exceeds the limit of 50 poise for jouleheated melting at $\mathrm{T}<1200^{\circ} \mathrm{C}$. The data shows that an acceptable Frit 18 glass containing 25-35 wt \% (amount expected for normal processing) of high aluminum sludge could not be made by in-can melting except at temperatures above $\overline{1150^{\circ}} \overline{\mathrm{C}}$. Since Frit 21 is definitely superior in terms of low viscosity; no further work on glasses containing Frit 18 was performed.

The viscosity of Frit 21 glasses containing high aluminum sludge is also above the 50 poise limit for normal loadings $(\sim 25$ wt $\%)$. For this reason, further frit composition development work has been done. The work will be documented in a later report.

\section{EFFECTS OF FRIT VARIABILITY ON VISCOSITY}

Small changes in the amount of all frit components except $\mathrm{SiO}_{2}$ did not change the viscosity greatly. However, as the $\mathrm{SiO}_{2}$ content of the frit varied from 50 to 55 wt $\%$, the viscosity of glasses containing $25 \mathrm{wt} \%$ composite sludge doubled, and exceeded the 50 poise maximum for good joule-heated melting. Thus, a maximum variability in the $\mathrm{SiO}_{2}$ content of Frit 21 of 51.5 to 53.5 wt $\%$ is recommended. The maximum variabilities allowed in the Frit 21 presently being used are $\pm 2.5 \mathrm{wt} \%$ in the total $\mathrm{SiO}_{2}$ content, and \pm 1 wt $\%$ in all other components.

Glasses were prepared containing the maximum amount of each frit component, with all other components reduced proportionately. These melts contained $75 \mathrm{wt} \%$ modified Frit 21 and $25 \mathrm{wt} \%$ composite sludge. The viscosities of these melts at $1150^{\circ} \mathrm{C}, 1050^{\circ} \mathrm{C}$, and $950^{\circ} \mathrm{C}$ are 1 isted in Table 5 . The most striking feature of the data in Table 5 is the strong dependence of the viscosity on the $\mathrm{SiO}_{2}$ content. At the maximum $\mathrm{SiO}_{2}$ content allowed by previous specifications $\left( \pm 2.5\right.$ wt $\%$ in $\left.\mathrm{SiO}_{2}\right)$, the viscosity at $1150^{\circ} \mathrm{C}$ exceeds the 50 poise limit for good joule-heated melting. Thus, material meeting the previous specification could perform unacceptably in a jouleheated melter. For this reason, a maximum variability of \pm 1 wt $\%$ (i.e. 51.5 to 53.5 wt \%) should be specified for the $\mathrm{SiO}_{2}$ content of Frit 21 .

Varying the other frit components caused relatively small changes in the viscosities, especially at $1150^{\circ} \mathrm{C}$. Thus, if a variability of \pm 1 wt $\%$ is specified for all frit components, the viscosities of the melts and hence, the vitrification process will not be significantly affected. 


\begin{tabular}{|c|c|c|c|c|}
\hline \multirow{3}{*}{$\begin{array}{l}\text { Erit Component } \\
\frac{\text { Varied* }}{\mathrm{SiO}_{2}}\end{array}$} & \multirow{3}{*}{$\begin{array}{l}\begin{array}{l}\text { Amount } \\
(w t \%)\end{array} \\
50.0 \\
52.5^{* *} \\
53.5 \\
55.0\end{array}$} & \multicolumn{3}{|c|}{ Viscosity (in poise) } \\
\hline & & $1150^{\circ} \mathrm{C}$ & $1050^{\circ} \mathrm{C}$ & $950^{\circ} \mathrm{C}$ \\
\hline & & $\begin{array}{l}30.0 \\
38.3 \\
45.0 \\
60.2\end{array}$ & $\begin{array}{r}78.3 \\
87.8 \\
114.0 \\
159.0\end{array}$ & $\begin{array}{l}262 . \\
274 \\
395 \\
578\end{array}$ \\
\hline $\mathrm{Na}_{2} \mathrm{O}$ & $\begin{array}{l}18.5^{* *} \\
19.5\end{array}$ & $\begin{array}{l}38.3 \\
34.8\end{array}$ & $\begin{array}{l}87.8 \\
85.3\end{array}$ & $\begin{array}{l}274 . \\
292 .\end{array}$ \\
\hline $\mathrm{Li}_{2} \mathrm{O}$ & $\begin{array}{l}4.0^{* *} \\
5.0\end{array}$ & $\begin{array}{l}38.3 \\
31.1\end{array}$ & $\begin{array}{l}87.8 \\
75.6\end{array}$ & $\begin{array}{l}274 \\
256\end{array}$ \\
\hline $\mathrm{TiO}_{2}$ & $\begin{array}{l}10.0 * * \\
11.0\end{array}$ & $\begin{array}{l}38.3 \\
36.6\end{array}$ & $\begin{array}{l}87.8 \\
94.0\end{array}$ & $\begin{array}{l}274 \\
339\end{array}$ \\
\hline $\mathrm{CaO}$ & $\begin{array}{l}5.0^{* *} \\
6.0\end{array}$ & $\begin{array}{l}38.3 \\
39.4\end{array}$ & $\begin{array}{r}87.8 \\
102.0\end{array}$ & $\begin{array}{l}274 \\
343\end{array}$ \\
\hline $\mathrm{B}_{2} \mathrm{O}_{3}$ & $\begin{array}{l}9.0 \\
10.0 \text { ** } \\
11.0\end{array}$ & $\begin{array}{l}43.7 \\
38.3 \\
40.2\end{array}$ & $\begin{array}{r}124.0 \\
87.8 \\
105.0\end{array}$ & $\begin{array}{l}452 . \\
274 . \\
344 .\end{array}$ \\
\hline
\end{tabular}

*A1 1 melts contain 25 wt \% composite sludge, and have frit components not listed in same proportions (by weight) as in Frit 21.

**Frit 21 . 


\section{EXPERIMENTAL PROCEDURES}

Glass samples were prepared by heating 150-200 g batches of frit and simulated sludges in an $\mathrm{Al}_{2} \mathrm{O}_{3}$ tube for at least 3 hours, at $1150-1200^{\circ} \mathrm{C}$. A platinum spindle suspended from a Brookfield viscometer was immersed in the melt, allowed to thermally equilibrate, and the relative shear stress measured. These values were then converted to viscosities using calibration factors determined from viscosity standards. The viscosity at $1150^{\circ} \mathrm{C}$ is most important since $1150^{\circ} \mathrm{C}$ is the reference melting temperature for SRP waste glass. Rates of shear could be varied from 0.5 to $100 \mathrm{~min}^{-1}$, and temperatures were within the range $750-1200^{\circ} \mathrm{C}$. Each viscosity reported is the average of a pair of measurements at each of three rates of shear (except when viscosities could not be determined for three rates of shear). The apparatus is shown schematically in Figure 8 . Periodically, the apparatus used in these studies was calibrated against a glass of known viscosity, NBS 710 , to ensure accuracy.

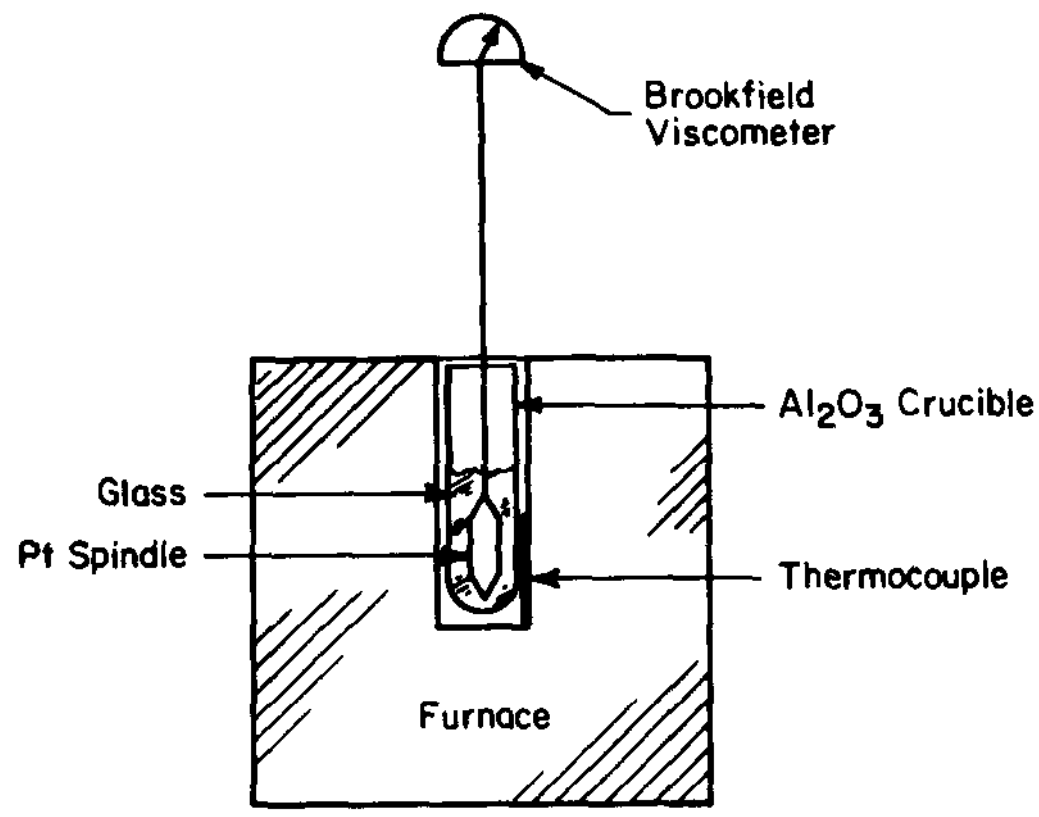

FIGURE 8. Schematic of Viscosity Apparatus 


\section{REFERENCES}

1. R. H. Burns. "Solidification of Low- and Intermediate-Level Wastes." At. Energy Rev. 9, 547 (1971).

2. R. M. Wallace, H. L. Hul1, and R. F. Bradley. Solid Forms for Savannah River Plant High-Level Waste. USAEC Report DP-1335, E. I. du Pont de Nemours and Company, Savannah River Laboratory, Aiken, SC (1973).

3. J. A. Stone, J. A. Kelley, and T. S. McMillan. Sampling and Analyses of SRP High-Level Waste Sludges. ERDA Report DP-1399, E. I. du Pont de Nemours and Company, Savannah River Laboratory, Aiken, SC (1976).

4. R. S. Ondrejcin. Chemical Compositions of Supernates Stored in SRP High-Level Waste Tanks. USAEC Report DP-1347, E. I. du Pont de Nemours and Company, Savannah River Laboratory, Aiken, SC (1974).

5. R. M. Wallace, et a1. "Solid Forms for Savannah River Plant Radioactive Wastes." p 9 in High Level Radioactive Waste Management, A.C.S. (1976).

6. J. A. Stone. Evaluation of Concrete as a Matrix for Solidification of Savannah River Plant Waste. ERDA Report DP-1448, E. I. Du Pont de Nemours and Company, Savannah River Laboratory, Aiken, SC (1977).

7. J. A. Kelley. Evatuation of Gizass as a Matrix for sotidification of Savannah River Plant Waste. Nonradioactive and Tracer Studies. ERDA Report DP-1382, E. I. du Pont de Nemours and Company, Savannah River Laboratory, Aiken, SC (1975).

8. J. A. Kelley. Evaluation of Glass as a Matrix for Solidification of Savannah River Plant Waste. Radioactive Studies. ERDA Report DP-1397, E. I. du Pont de Nemours and Company, Savannah River Laboratory, Aiken, SC (1975).

9. G. H. Thompson. Evaluation of Mineralization Processes for SRP Wastes. ERDA Report DP-1389, E. I. du Pont de Nemours and Company, Savannah River Laboratory, Aiken, SC (1975). 
10. J. A. Stone. Separation of SRP Waste Studge and Supermate. ERDA Report DP-1441, E. I. du Pont de Nemours and Company, Savannah River Laboratory, Aiken, SC (1976).

11. I. Horowitz. "Mehrteilige Wannenofensysteme für die Electroschmelze des Glases." Elektrowärme Intermational, $34 B$ (\#), 137 (1976).

12. R. B. Bird, W. E. Stewart, and E. N. Lightfoot. Transport Phenomena, J. Wiley and Sons, New York, 1960, pp 3-29.

13. S. G. Brush, "Theories of Liquid Viscosities," Chem. Rev. $62,513(1962)$.

14. S. Glasstone, K. J. Laidler, H. Eyring. The Theory of Rate Processes, McGraw-Hill, New York, Chapter IX (1941).

15. G. S. Fulcher. "Analysis of Recent Measurements of the Viscosity of Glasses. I." J. Am. Cer. Soc. 8, 339 (1925).

16. G. S. Fulcher. "Analysis of Recent Measurements of the Viscosity of Glasses. II." J. Am. Cer. Soc. 8, 789 (1925).

17. C. M. McDowell and F. L. Usher, Proc. Roy. Soc. A131, 409, 564 (1931). 